\title{
The Nature of Portuguese Cinema: Environment on the Silver Screen
}

\author{
PATRÍCIA VIEIRA \\ Georgetown University
}

\begin{abstract}
This article analyzes the representation of nature in Portuguese cinema from the silent era to contemporary productions. I argue that cinematic depictions of the environment reflect the socio-economic and political changes Portugal went through in the past century. Early films showcased natural beauty, together with local traditions, and created what I define as a "domesticated natural sublime." Estado Novo filmography portrayed nature as a godlike entity that could both be the source of adversity and a loving, nurturing mother and presented authority figures as instantiations of this powerful force. Salazarist films also praised the countryside to the detriment of city life, a dichotomous view of the environment that continued in movies from the democratic period. In more recent work, we witness the development of an ecological consciousness, as films meditate upon the relation between humanity and the environment in late modernity.
\end{abstract}

Keywords: Regionalism; domesticated natural sublime; environmentalism; ecology

Nature inconspicuously creeps into film, insinuating itself into a shot, framing a sequence and ultimately coloring the entire movie as the backdrop for human action. Unlike literary works, where descriptions are optional, cinema cannot but depict the landscape - the sky, the sea or a mountain, plants and animals- 
as the background for events captured by the lens. ${ }^{1}$ Often out of focus, decorating the edges of the frame where humans take center stage, the representation of natural elements in many cinematic productions is symptomatic of a widespread attitude towards the environment, which is taken for granted as décor or as a commodity that is and always will be simply there, ready for human appropriation. But this unconscious, almost forgetful portrayal of nature in many films betrays our dependence upon the environment, the variations of which end up structuring the progression of movies and determining their various sequences.

Even in the case of films where the plot takes place almost entirely indoors, as in Hitchcock's Rear Window (1954), or in an overtly artificial setting, like in Lars von Trier's Dogville (2003), in which natural elements are signaled by painted outlines with labels such as "bushes," nature remains a crucial element. Precisely because of the paucity of natural referents, the few environmental details that make their appearance in these movies become laden with meaning. In Hitchcock's film, for example, L. B. Jefferies points to the size of his neighbor Lars Torwald's plot of zinnias as proof that he murdered his wife (Duncan). And the symbolism of the apples that make their appearance in Dogville, with their inevitable Biblical connotations, is similarly significant.

In many cases, cinema foregrounds the environment or parts thereof to enhance the reach of human action. Natural elements work as a correlative for emotions and desires, mirroring and amplifying our conduct. Fernando Lopes's Uma abelha na chuva (1971), an adaptation of Carlos de Oliveira's homonymous novel from 1953, is a salient example of the conscious use of the environment to reinforce certain aspects of human behavior. The pervasive rain and desolate landscape contribute towards creating the somber mood of the film that portrays the stagnant social milieu of Portugal during the Estado Novo dictatorship (1933-1974), epitomized in the failed marriage of a noblewoman to

\footnotetext{
1 Though landscape, nature and environment are concepts with a very different history and signaling competing understandings of the world-landscape as a background for human action and a site of aesthetic contemplation; nature as opposed to human culture; and the environment acquiring environmental connotations in the last few decades - the terms will often be used as synonyms in this article, unless otherwise noted. Even though a rigorous differentiation between these concepts is not undertaken here, some terms are more suitable than others when it comes to understanding Portuguese film's approach to nature. Whereas landscapes feature prominently in "typically Portuguese" movies, for instance, the environment becomes more relevant in contemporary cinema.
} 
a rich, bourgeois landowner. The damp, dreary settings are a metaphor for the loveless relationship between the two main characters, while Maria dos Prazeres's brutal flogging of a horse is a clear outlet for her unfulfilled sexual drive. The quiet, foggy surface of the lake hiding the body of a young women who committed suicide by drowning stands for the repression of both sexual desire and social struggle, forced out of view under a cloak of normalcy. Society is, like nature itself, drowning in a swamp, its vitality sapped by the chilling effect of the conservative Estado Novo ideology.

But nature cannot be reduced to a mere backdrop for cinematic action, either reproduced unconsciously or foregrounded as a counterpart to and metaphorical illustration of human dilemmas. The environment often plays an independent role and becomes a character in its own right, acting in dialogue with or in opposition to human protagonists. This article focuses on Portuguese films that overtly thematize nature, highlighting, problematizing, or questioning the representation of the environment on the silver screen. I trace the different modes of featuring natural elements in the country's cinema: the early attempts to depict natural wonders, in conjunction with local customs and traditions, so as to create a domesticated natural sublime; the Estado Novo's dichotomous portrayal of nature both as source of adversity and as a loving, nurturing mother and the regime's praise of the countryside to the detriment of city life; and, finally, the development of an incipient ecological consciousness in more recent cinema. Excluding nature and wildlife films, our goal is to analyze the portrayal of nature in its relationship to human-led plots in order to tease out the specificities of the Portuguese representation of the environment in film.

\section{Typically Portuguese Nature}

From its early days onwards, Portuguese cinema has depicted particularly striking or impressive landscapes in a bid to showcase the country's natural wonders. This display of dramatic scenery aimed to bring the countryside closer to urban dwellers, who comprised the vast majority of filmgoers, and to make them acquainted with regions they would have otherwise not known. Furthermore, filmmakers hoped to bring Portuguese natural beauty to the attention of an international audience and therefore encourage tourism from abroad. Cinema was understood as a means to pursue a nationalistic agenda that 
aimed to bolster the country's self-image internally, and to increase its prestige internationally, using the environment as a tool to advertise Portugal both to national urbanites and to foreigners (Baptista 87-89).

During the silent era, the concept of the "filme tipicamente português" gained currency as a designation of movies that featured the most salient aspects of Portugal's natural and cultural landscapes. Tiago Baptista argues that these films were praised for their efforts to display a specifically Portuguese mode of being in the world - a Portuguese ser and sentir - that contrasted with foreign films bringing new and potentially pernicious ideas to the nation's filmgoers (86). As international productions flooded the Portuguese market, the country's intellectuals feared a "desnacionalização" of the population, influenced by a foreign mindset - a tendency that could only be countered by a strong investment in "typically Portuguese" films (90-91). Where the action of these films took place was of particular concern, as they were entrusted with the function of displaying natural beauty, monuments, and regional traditions.

The view of cinema as a vehicle to exhibit and even advertise the vague notion of a national character continued during the Estado Novo (Baptista 84). António Ferro, head of the regime's Secretariado Nacional de Propaganda from its creation until 1949, used the designation "filmes regionais e folclóricos" to refer to productions that depicted both the landscape and local customs in an attempt to encapsulate "portugueseness"" (63). While Ferro, a Modernist avantgarde intellectual, was not particularly impressed by the emphasis on rurality that was a hallmark of "regional and folkloric films," he recognized the significance of these productions within the larger propagandistic project of the Estado Novo. The more natural and therefore more perfect way of life was, according to the regime, one that was in tune with the environment. Salazar, the Estado Novo's prime minister and de facto ruler, considered his government a means to protect this symbiosis with natural elements, which he considered to be a distinguishing marker of Portuguese culture. He aimed to structure Portuguese society as a large village, the countryside mode of existence being considered the most appropriate form of social organization. A reactionary regime, the Estado Novo regarded the social hierarchy and traditional mindset

\footnotetext{
2 The Secretariado Nacional de Propaganda was renamed Secretariado Nacional de Informação, Cultura Popular e Turismo in 1944; in 1968, it became the Secretaria de Estado da Informação e do Turismo.
} 
of rural Portugal as a model to be emulated by the entire nation, an ideal that could be brought to the population through the use of cinema as a propagandistic tool. $^{3}$

Documentary films were more easily tailored to present "typically Portuguese," as well as "regional and folkloric" elements, since nature could be featured as the main topic of the movie, but even fiction films went out of their way to display national landscapes and customs. Leitão de Barros's productions about the sea are cases in point. Nazaré, praia de pescadores (1929), for instance, is a short documentary that depicts both the imposing beauty of the sea and the traditions of the local fishermen. But even in Barros's Maria do Mar (1930) and Ala-arriba! (1942), the plot becomes little more than a thinly veiled pretext to portray Nazaré and Póvoa do Varzim, respectively. As Barros himself admits, Ala-arriba! is more than anything "um filme sobre os hábitos, leis, costumes e tradições dos pescadores da Póvoa" (qtd. in Ribeiro 441).

It is telling that, in "typically Portuguese" and "regional and folkloric" films, the environment encompasses both natural and human elements. Unlike the American tradition, where nature is often synonymous with wilderness, the Portuguese conception of the environment does not establish a strict separation between nature and culture. Such indistinctness could, on the one hand, be interpreted as a judgment passed on the country's rural population. Seen through the lens of filmmakers and of bourgeois moviegoers from the city, rural people seemed to be deprived of agency and fitted into an exoticized backdrop that appeared to be as immutable as nature itself. In Leitão de Barros's aforementioned films, as in several other productions from the first decades of the twentieth century, both the natural landscape and rural traditions are portrayed as timeless, a bastion of Portuguese customs, the abiding character of which was a value in and of itself.

Early Portuguese cinema tended to present change as threatening. The Estado Novo accentuate this feature, since alterations or nonconformity, political or otherwise, could potentially imperil the regime. Jorge Brum do Canto's films set in rural environments exemplify this aversion to transformation that would compromise a traditional way of life. In Canção da

\footnotetext{
${ }^{3}$ For a detailed analysis of the Estado Novo emphasis on natural living and the ways in which this rhetoric was represented in film, see Vieira 83-94.
} 
terra (1938) emigration is regarded as a potential threat to the rural community of the island of Porto Santo; smuggling and the abandonment of agricultural tasks are a danger facing the population from the mountainous region of northern Portugal in Lobos da serra (1942); and, in A Cruz de ferro (1967), it is the greed of a group of villagers that destroys the precarious balance between nature and village life. As a rule, these and other movies highlight the similarities uniting the environment and rural communities. Both could experience natural or social upheavals, but the end of the films and the denouement of their plots coincided with the neutralization of change and with a return to the environmental and communal status quo.

\section{A Domesticated Natural Sublime}

The imbrication of the landscape with the communities that directly depended upon the environment for their livelihood - farmers, fishermen, and so on-in Portuguese cinema, to the point that the two are portrayed as an intertwined and enduring given, betrays an underlying conception of the world as, in essence, a spiritualized, humanized cosmos. Nature can certainly have moments of hubris, when it challenges human practices, but it is also amenable to management, control, cultivation, and usage. This understanding of nature necessarily impacted its aesthetic representation, since environmental elements were regarded both as autonomous, fierce forces and as tame, docile entities. I call the aesthetics of depicting nature in early Portuguese film a "domesticated natural sublime." The oxymoron latent in this expression-the terror-inducing sublime is, by definition, triggered by a nature that resists domestication and any imposition of human-made boundaries - is purposeful, as it captures the particular configuration of nature as independent and, at the same time, inextricably linked to humanity, characteristic of the Portuguese way of portraying the environment in cinema. Manoel de Oliveira's short, silent documentary Douro, faina fluvial (1931) epitomizes this view of the environment that left an indelible mark on subsequent Portuguese filmography.

Oliveira's film begins with a statement, shown onscreen immediately after the credits, that introduces its subject-matter: "O Douro, rio português, possui uma vida própria característica, que justifica a sua paisagem marginal e as atitudes da gente que em sua volta trabalha." This is not a film solely about a 
river or merely about the people who inhabit its banks but about the connection between the two. The movie seeks to portray the Douro and those who live off the river, a goal encapsulated in its very title, which can be translated as Douro, Riverine Toil. Significantly, the first shot of the film is not of the river but of the intense beam of a lighthouse shining and disappearing in the night, followed by a cut to daylight images of powerful waves. The third shot brings together the two previous ones as we see the waves hitting a long pier that ends in the lighthouse, presumably the one located at the mouth of the Douro river.

In the film, the lighthouse ostensibly stands for the human attempt to master the wild, rough environment of the river's mouth, symbolized by the high waves. The awe-inspiring natural sublime of the river meeting the sea is therefore domesticated by human intervention: it does not completely lose its fierceness but its force is harnessed by human efforts. The third shot dialectically unites the two elements, human and natural, and thus sets the tone for the rest of the movie. After the initial lighthouse sequence, we see a steamer moving upstream, towards the city of Porto and away from the sea. Images of the traces left on the water by the steamer's fast pace are cross-cut with new shots from the lighthouse to indicate the resistance of the river to navigation, which was made possible thanks to inventions such as lighthouses, a symbol of human ingenuity. The Douro is thus implicitly equated with a wild beast that has been tamed and rendered useful for those who live on its banks. The numerous shots of the iconic Luís I bridge connecting the two banks of the river in the city of Porto, which immediately follow the sequence with the steamer and the lighthouse, stand for this appropriation of the river for human purposes that is the theme of the rest of the movie.

The idea that the life of the river "explains" the attitudes of the people living on its banks might be interpreted as a deterministic approach to the connection between nature and humanity. But what the film focuses on is a give-and-take relationship, whereby humans have learned to take advantage of the Douro to further their goals. Shot almost entirely in the Ribeira area of Porto, the neighborhood located right on the water, the movie highlights economic activities made possible by the river, especially fishing and the transportation of people and goods in sailboats and steamers. Far from nostalgically harking back to a time of idealized, bucolic simplicity, the film fully embraces modernity. Oxen carts used to carry merchandise to and from 
the river appear side by side with countless shots of trucks, trains and even airplanes that symbolize the modernization of Porto. The domesticated sublime

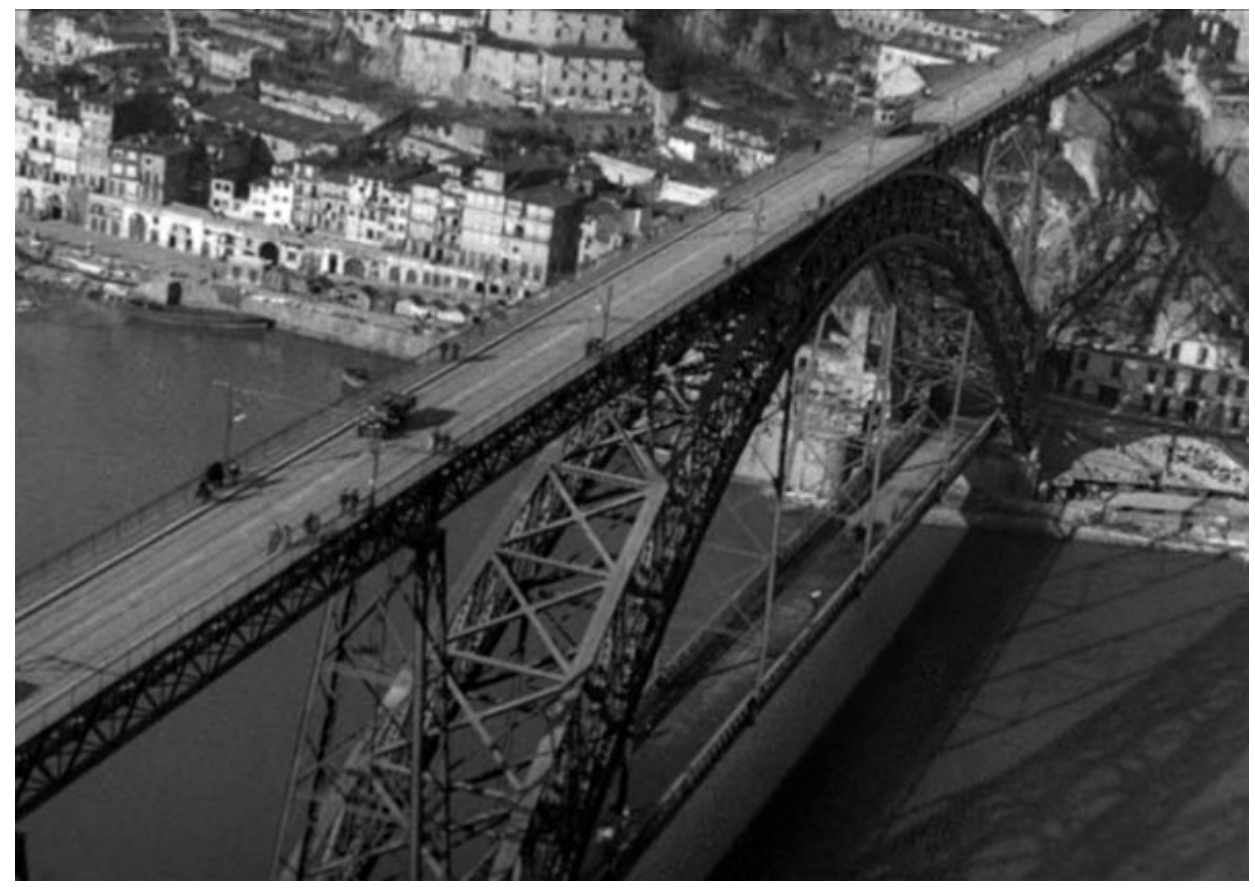

of the river, whereby the might of the Douro is used by the inhabitants of the city, gives way towards the end of Oliveira's movie to what one might define as an "industrial sublime," a sense of awe when faced with technological and industrial progress that is unique in Portuguese cinema from this period and that will only reappear much later in movies such as Fernando Lopes's As palavras e os fios (1962). ${ }^{4}$

Douro, faina fluvial comes full circle with a sequence depicting a steamer leaving Porto and moving out to sea, in an inverse path to the boat seen in the

\footnotetext{
${ }^{4}$ The industrial sublime has, of course, been part of cinema from its inception, with The Arrival of a Train at La Ciotat Station (1895) by the Lumière brothers being a good example of this aesthetic. Made possible by techno-scientific development, it is not surprising that cinema would embrace modernity in its subject matter. While Oliveira's movie follows in the footsteps of this glorification of modernity, other filmmakers were more critical of industrialization. A case in point is Charlie Chaplin's comedy Modern Times (1936).
} 
beginning. The film ends with more images of the lighthouse at dusk and the final shots, like the first ones, show the beam of the lighthouse shining in the dark. The structure of the film leads viewers to believe that they have witnessed a regular day in Porto, the events portrayed in the movie an example of activities that routinely take place on the river's banks. Framed by the cyclical, daily rhythm of nature, the movie itself exemplifies a domesticated natural sublime, as does the art of cinema as a whole; it combines the environment where the action takes place with the artistic skill of the filmmaker who captures it on camera. If the domesticated natural sublime unites nature and people in an intertwined whole, cinema brings together the landscape and its aesthetic portrayal to the point where one can no longer determine where natural beauty gives way to its skillful, artistic representation.

The domesticated natural sublime was a staple of Portuguese cinema throughout the Estado Novo, all the way to the Novo Cinema period starting in the 1960s and extending to contemporary productions. The Estado Novo idealized rural life and the indelible link between places and people. The regime touted the superiority of an existence in tune with nature as opposed to the supposed artificiality of urban living, where people might be exposed to politically dangerous ideas. Films such as those directed by Leitão de Barros and Jorge Brum do Canto, mentioned above, exemplify this praise of a mode of being that, despite some challenges, remains faithful to nature. If humans need to adapt and conform to natural determinants, nature is also shaped by human toil, the domesticated natural sublime being the aesthetic mode of representing this interdependence.

Oliveira's, Barros's and, albeit to a lesser extent, Brum do Canto's films mentioned above can be considered ethnofictions, that is, movies that combine ethnographic, documentary footage with a fictional plot. This trend continues in New Cinema productions such as Oliveiras's O acto da primavera (1962), António Reis and Margarida Cardoso's Trás-os-Montes (1976), as well as in contemporary films like Miguel Gomes's Aquele querido mês de agosto (2008). The ethnographic documentary, in the footsteps of Douro, faina fluvial, has also had contemporary followers. An example is Jorge Pelicano's Ainda há pastores? (2006), which portrays the lives of shepherds living in a secluded valley located in Serra da Estrela, continental Portugal's tallest mountain range. Keeping to an ancestral routine with just a few modern additions-radio, a cell 
phone and, with the arrival of electricity to the valley, a television and a fridge - these shepherds are latter-day avatars of the fishermen and farmers of Barros's and Brum do Cantos's films. The magnificent images of the valley have to be interpreted in conjunction with the sequences depicting the shepherds' harsh routine. Far from the idealized pastoral tradition of literature, these real-life shepherds have to withstand biting cold, long working hours, and social isolation in order to tend their animals. The shot of a shepherd's silhouette, leaning against his rod and towering over the mountainous terrain as he watches his flock, is a perfect image of a domesticated natural sublime - the aesthetic feeling triggered by a wild environment brought into the fold of civilization by the efforts of those who make a living off nature.

\section{Nature as God}

The domesticated natural sublime aesthetics created in "typically Portuguese" films hinged upon a conception of the environment that, though tamed by human efforts, was an unpredictable, wild entity that could act up and spin out of control at any moment. If human civilization has been, to a large extent, the history of learning to cope with and at times to strenuously fight against the dictates of the environment, cinema could not but express this struggle. From Hitchcock's renowned Birds (1963) to more recent disaster movies that envision a world devastated by apocalyptic floods, freezing temperatures, and droughts, or those that bring to the screen natural catastrophes like earthquakes and tsunamis, cinema has a long tradition of portraying nature as a problem. Portuguese filmography from the Salazar period replayed this age-old clash between humanity and the environment with a twist.

In movies produced in the first three decades of the Estado Novo, before the rise of the Novo Cinema movement, the role of nature evoked the function of the Christian God in Biblical narratives. An overtly devout politician, Salazar brought the doctrine of the Church to bear on his government. It is therefore not surprising that Estado Novo cinema, often directly supported by the regime through film subsidies, would reproduce Catholic values. "Regional and folkloric" films, in which the environment played a crucial part, depicted nature in two opposing but ultimately complementary ways: as an angry, punitive force that thwarts and often destroys human plans or as a nurturing, 
tender mother upon which humanity can rely for its livelihood. Such dichotomous representation is reminiscent of the contrast between the exacting, punishing god of the Old Testament and the caring, compassionate deity of the New Testament. Nature was thus portrayed as animated, ensouled and godlike_-god or/as nature, as Spinoza put it in his Ethics.

In Maria do Mar and Ala-arriba!, Leitão de Barros presents the sea as a powerful entity that endangers the lives of members from the two fishing communities. In Maria do Mar, Manuel's father is killed in a shipwreck while fishing, and the female protagonist, who gives the movie its title, almost drowns when she is caught in a whirlpool while swimming-she is conveniently saved by Manuel, an episode that cements their love. Ala-arriba! also hinges upon an accident that takes place during a fishing expedition. This time, João risks his life to save Julha's father from drowning in a shipwreck, which paves the way to their marriage at the end of the movie. The sea is here an unpredictable natural force that must be contended with, the fishermen forced to learn its ways to survive.

Other Estado Novo cinematic productions highlight the difficulties experienced by farmers who struggle against the arbitrariness of nature. Brum do Canto's Canção da terra focuses on the droughts that periodically strike the island of Porto Santo, decimating crops and even cattle that are the livelihood of the local rural community. In Lobos da serra, it is a flood that destroys agricultural fields and jeopardizes the continuation of village life. And in Henrique Campos's Um homem do Ribatejo (1942), nature takes an even higher toll: Manuel learns during his wedding celebrations that a bull has killed his brother, the same animal that had already killed his father some time before, and the film ends with a devastating flood that ravages the land. In all of these examples, the environment puts human beings through trials and tribulations, inflicting suffering and testing their fortitude in the face of adversity.

While Salazarist cinema shows how the natural world can, at times, put human beings through periods of distress, it also emphasizes that nature rewards perseverance and hard work and provides sustenance to those who remain faithful to a traditional way of life as fishermen or farmers. In Leitão de Barros's productions, the villages of Nazaré and Póvoa live off the sea and, notwithstanding the deadly accidents portrayed in the films, there is hope for the future as the marriages at the end of both movies point toward a new 
generation of fishermen who will carry on their ancestral way of life. In Canção da terra, the drought eventually ends and, with the rain, prosperity comes once again to Porto Santo. The protagonist, Gonçalves, reflects at this point that "a terra dá trabalho, dá, mas mais cedo ou mais tarde também dá tudo," thus reinforcing the rural ethos. Um homem do Ribatejo also ends with a harbinger of better times. The protagonist manages to save his boss's cattle from the flood, along with his own wife, who then tells him that she is pregnant in a symbolic promise of renewal. In Lobos da serra, the destruction caused by the flood is overcome when the community comes together to clean the debris left in the fields by the high water. The chief of police talks to the local priest and the two - the local secular and religious authorities - reach the conclusion that farming leads to happiness, since God himself told human beings to "trabalha[r] a terra com o suor do teu rosto." Akin to the Biblical Job, humanity needs to strive to overcome hardship, persevere in its resolve to work with nature, and resiliently stay the course until better days come. Nature rewards those who remain faithful to it, and it can be a caring, motherly force that provides for human needs.

The view of nature as something akin to the Christian God, a Janus-faced being who can both punish and benefit humanity, had far-reaching ideological and political consequences. The goal of the Estado Novo was to organize Portuguese society following natural models. The regime posited a seamless transition from the natural world to social organization, with those in positions of power equated to elements of the environment that could sometimes exert violence over but would ultimately protect the Portuguese people. Salazarism envisioned a hierarchically designed social order, a modern version of the medieval scala naturae, or ladder of nature, as the foundation for a conservative, patriarchal form of government. God as/or nature stood at the apex of this pyramidal structure, followed by Salazar and other political leaders, then by others in positions of power - the clergy, the police, business ownersin the social domain, and by the pater familias in the private realm.

Like the dictates of god/nature, the commands of Estado Novo authority figures might at first appear arbitrary. What the filmography of the time suggests is that natural deeds, like the rules of politicians, had an underlying reason, which was usually revealed at the end of the movies, when problems were surpassed and the community thrived once again. If the Portuguese 
obeyed these precepts, they would receive their recompense (similar to the fishermen and farmers in the films) in the form of a stable, peaceful and dignified existence. To be clear, Estado Novo filmography, and the regime itself, did not make the case for Spinozan-style pantheism, for an immanent deity dispersed in nature and present in all beings and things. Nature was similar to the Christian God and, mutatis mutandis, to the political leaders of Salazarism, insofar as it had a virtually unlimited power to impact upon the lives of the Portuguese. The movies strove to inculcate the notion that this was ultimately a benign power, the exercise of which was to everyone's advantage.

Estado Novo cinema inherited from silent films the notion that there was no strict separation between nature and society. While "typically Portuguese" movies emphasized the beauty of Portuguese landscapes and the close symbiosis linking the Portuguese and their traditions to the environment, however, Salazarist filmography added another layer to this worldview. Nature was often presented as an all-powerful godlike entity acting upon human communities, a force whose actions might at first appear unfathomable but whose benevolent intent would surface in the end. The continuum extending between nature as/or god and society meant that political, religious, and other authority figures were often depicted as powers akin to natural elements, who shaped the lives of the Portuguese. Cinema underscored that the relationship between humanity and the environment could not be otherwise and, by implication, that the ties binding the Portuguese to their leaders could also not be altered. The Estado Novo was regarded as a faithful translation of the natural world into the communal domain, the most natural form of social organization and, therefore, the only mode of existence suitable for the Portuguese.

\section{Countryside vs. Cities}

Already during the silent period and later, in Salazarist times, cinema tended to pit the decadent life of the city, permeable to foreign influences and to deleterious new ideas, against the tranquil existence of the countryside, where the Portuguese lived in tune with nature. In António Lopes Ribeiro's Gado bravo (1934), the Viennese cabaret singer Nina seduces the Ribatejan bullfighter Manuel Garrido, a situation that compromises Manuel's relationship with his Portuguese fiancée, Branca. Nina stands for the loose morality 
attributed to urbanites and for the debasement of customs associated with foreigners. Both features endanger the simple existence of Manuel's Ribatejan household when Nina moves in with him shortly after their first encounter. It is only with Nina's death that life resumes its due course on Manuel's farm: he marries the tradition-oriented Branca and embraces his duties as head of his country estate.

In this and several other movies, the city functions as a siren song, beckoning young males away from the countryside and therefore threatening the reproduction of established social structures. Leitão de Barros's As pupilas do senhor reitor (1935), an adaptation of nineteenth-century writer Júlio Dinis's homonymous novel, revolves around Daniel's (Paiva Raposo) difficulty in adjusting to the daily routine in the village where he was born after spending his student years in the university town of Coimbra. In Chianca de Garcia's Aldeia da roupa branca (1939), as in Gado bravo, the male protagonist, Chico, falls in love with a fado singer, Hermínia Silva, and considers abandoning his childhood sweetheart and family business to move from the countryside to Lisbon to be close to her (Vieira 165-69). Augusto Fraga's Sangue toureiro (1958), replays this same plotline. Eduardo, the scion of a wealthy Ribatejan family, falls in love with a city performer, the fado singer Maria da Graça (played by none other than Amália Rodrigues), and threatens to abandon the management of his family estate to marry her.

Estado Novo cinema was responding to a social trend, whereby young people, and especially young men, who tended to be more independent within Portugal's conservative social framework, left the countryside to try their luck in the city. The various women artists who lured men away from rural settings in the movies embody the corruption of urban life decried by Salazarist ideology: the adoption of debased foreign habits that translated into loose customs and an independent lifestyle inappropriate for a good housewife. Moving away from nature, city artists strayed from the simple, natural existence praised by the regime and exemplified the risks that led unsuspecting men away from the straight and narrow path of morality. Movies warned against this nefarious trend by highlighting the pitfalls of urban living and unabashedly praising the natural existence in the countryside. The symbiosis between nature and human activities depicted in cinema from the "typically 
Portuguese film" time onwards was perceived as under threat by city habits encroaching on rural mores.

The Novo Cinema movement represented a stylistic and thematic break away from the filmography of the first decades of the Estado Novo, but it nevertheless persisted in representing the city as a potentially dangerous space. Paulo Rocha's Os verdes anos (1963), considered to be one of the founding films of Novo Cinema, is a case in point. The movie begins with the credits superimposed onto a series of shots of rural landscapes - fields, orchards, a brook - to the poetic guitar music of Carlos Paredes. In the last of these shots, the camera pans from the bucolic vistas of a tree-lined hill to tall suburban apartment buildings, while a male voice-over describes his feelings when he first saw Lisbon. In line with previous movies, he compares the city to a woman who needs to be slowly and carefully conquered, lest she escapes one's grasp. While earlier Estado Novo films ended with the return of males to the fold of nature and to their village communities, Os verdes anos narrates the fate of those who move permanently to the city.

Viewers soon find out that the voice-over belongs to the uncle of the movie's protagonist, Júlio, who comes to Lisbon to work as a shoemaker's apprentice. Not heeding his uncle's warnings about the dangers the city poses for rural newcomers, Júlio gets involved with a maid called Ilda, who is more savvy than him when it comes to navigating the urban landscape. Feeling increasingly ill at ease and out of his depth in the hostile environment of the city, Júlio proposes to Ilda to integrate and carve a space for himself in the capital. When she snubs him, he stabs her in her home. The last sequence of the film is symptomatic of the standoff between the rural and urban settings. On the run and disoriented the night after the murder, Júlio crosses a road and is almost run over by traffic. The movie ends with three increasingly long and high angle shots of Júlio in front of the cars, an apt image of his powerlessness when facing the complexity of city life.

Os verdes anos depicts urban surroundings as a menacing environment, but the film also shies away from idealizing the countryside. A far cry from the natural world of the seaside and the countryside represented in previous films that, regardless of occasional disruptions, nurtured fishermen and farmers, rural existence is presented in Rocha's movie as a rough, bitter life. As Júlio's uncle 


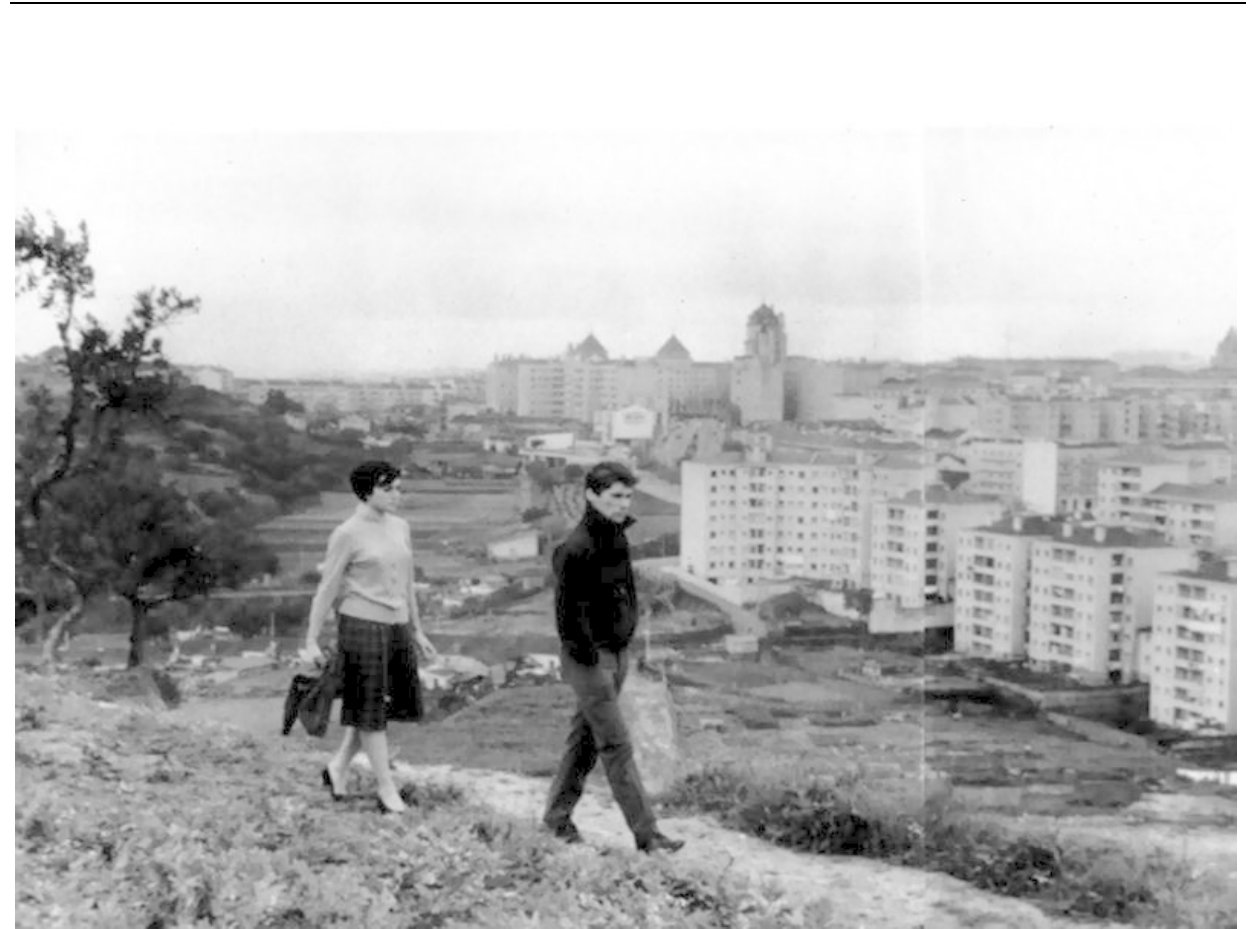

puts it, if the boy makes it in the city, he will be "menos um a passar mal" in their village. Os verdes anos depicts a society out of sync with its surroundings. At home neither in the impoverished countryside nor in urban settings, many Portuguese were left in limbo, unable to fit into a changing social landscape. This malaise was clearly rooted in the Estado Novo totalitarian government, but the oppressive political circumstances were not the sole cause responsible for the unease depicted in cinema. At a time of rapid modernization, Portuguese society was losing touch with its ancestral links to the natural world and found itself unable to cope with the challenges of the increasingly accelerated pace of urbanization. In contemporary films, this separation between people and the environment is exacerbated, even as we witness the emergence of a new ecological consciousness.

\section{Endangered Nature}

Post-1974 cinema reflects the deep transformations in Portugal's approach both to the countryside and to the environment with which rural life is associated. João Botelho's Um adeus português (1985), for example, paints a picture of 
village life as a place for older people, the new generation having moved to big cities. In the film, an elderly couple, Raul and Piedade, travels to Lisbon to visit the widow of their eldest son, who was killed in the colonial war some years before, as well as their younger son, who also lives in the city. Similar to Os verdes anos, the movie depicts Lisbon as an impersonal, cold environment that soon drives Raul and Piedade back to their farm. Young people, however, never set foot in the village estate, which, the film suggests, will be abandoned once the old couple passes away. Um adeus português portrays a shift from a rural to an urban setting as the center of Portuguese society. Even though the film is framed by the natural landscape of Minho in the beginning and at the end of Raul and Piedade's trip, most of the action takes place in Lisbon. Cities are now the focal points of existence, and the countryside is represented as a picturesque but increasingly depopulated region.

The cinematic view of the countryside through the eyes of city-dwellers as an unfamiliar, almost exotic place goes back to the "typically Portuguese" and "rural and folkloric" films produced for urban filmgoers. What changed in the post-Estado Novo period was that, with the overwhelming majority of the Portuguese population living in urban or suburban areas, the portrayal of the countryside and of the natural world is now tinged with nostalgia. While, in previous films, the labor of fishermen and farmers contending with hard natural conditions evoked all too real circumstances, such an existential struggle to eke out a meager living from nature has virtually disappeared. Rural customs, habits, and celebrations are pictured as quaint traditions to be documented lest they fade away, as yet another casualty of urbanization.

Gomes's Aquele querido mês de agosto touches upon some of the predicaments currently facing the Portuguese countryside. The film consciously thematizes its ambiguous genre, halfway between a cinéma vérité or direct cinema-style documentary and the less experimental ethnofiction. An urban crew goes to the mountainous region of Beira, ostensibly to film a love story between two teenagers. However, the first half of the movie focuses mostly on the activities that liven up the region during the month of August, when many urbanites and foreign tourists visit the countryside, and a large number of immigrants living abroad return to their hometowns in northern and central Portugal to spend their summer holidays. The title of the movie, adapted from a song by pop singer Dino Meira, refers precisely to the longing felt by 
immigrants who go back to their hometowns in the month of August. The melody is often heard in the summer concerts that take place throughout the villages, played by semi-professional bands like the one portrayed in the film.

Harking back to "typically Portuguese" and "rural and folkloric" films, Aquele querido mês de agosto documents local traditions, such as religious processions and other celebrations, together with the natural environment: mountains, a river and a fluvial beach, the forest, and so on. As in older movies, nature is not a pristine environment, devoid of human intervention. The beach is packed with swimmers and the peaceful village of Góis is disturbed by a large rally of motorcycle enthusiasts. In a telling shot, the camera films first an impressive, empty mountain range and then travels to capture the many wind turbines that dot its summits a little further on. Both the bikers and the turbines point to the rapid modernization of Portugal and to the combination of traditional culture with development in rural areas.

While the wind turbines are already indicative of an emerging environmental consciousness and of the great strides the country has made in securing renewable energy sources, the imminent threat of forest fires is the most open environmental statement in the film. The movie includes several shots of firefighters' trucks patrolling the forests and even a child's drawing of one of the trucks that shows how firefighting has become ingrained in local society. Lookout towers from which someone monitors the mountains day and night to alert firefighters as soon as smoke is spotted remind viewers of the ravaging fires that plague Portugal every summer. We see the mountains through the binoculars of one of the firefighters, and another shot shows a map of the region punctuated with red dots, presumably signaling lookout towers. The film underlines human control over the mountain ranges of Beira, thoroughly mapped and constantly scrutinized.

In Aquele querido mês de Agosto, the close connection to the natural world distinctive of societies living primarily off the fruit of the land has disappeared, as everyday human activities are increasingly detached from nature and its rhythms. Not only the city dwellers who visit Beira but even the local inhabitants' relationship to the landscape has changed and tasks such as cattle raising or agriculture are almost completely absent from the movie. Rather than a mighty, sometimes wrathful, god that can exert its force over powerless humans, nature is represented as fragile and in need of constant protection from 
the harm that others might inflict upon it. The forest fires in particular stand for the vulnerability of the environment, endangered by the advancement of modernity in Portugal. The fictional plot of the film ends when the threat turns into reality and a fire breaks out in the mountains. Images of the red and orange blaze are accompanied by the sound of wood burning and by a kitschy love song playing in the background. The lyrics of the song ostensibly allude to the amorous story between the protagonists. However, one might interpret it as a subtle comment upon our relationship to nature. The sorrowful words evoking the grief caused by a lost lover are an apposite statement about our current approach to the environment, only thoroughly appreciated when it is under threat and on the verge of collapse, destroyed, for instance, by a fire. Gomes's

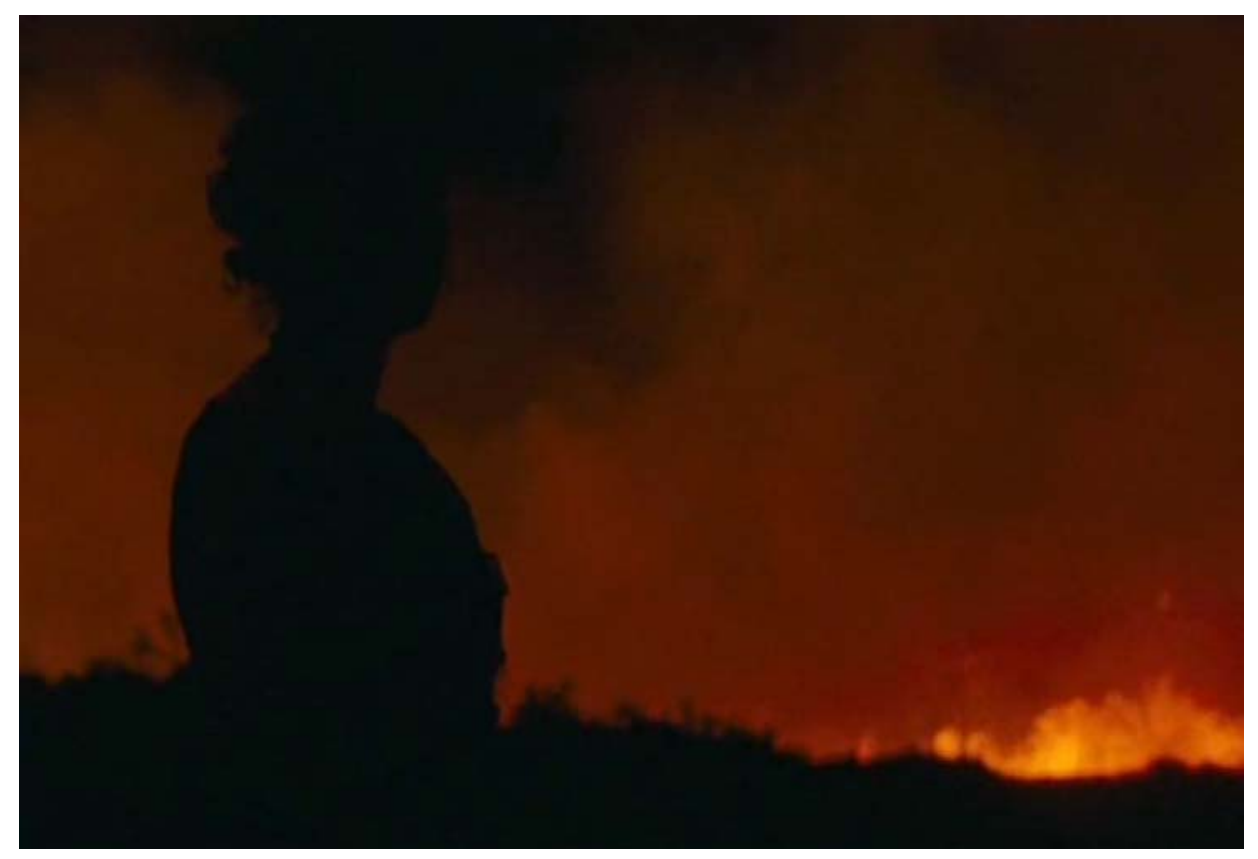

film portrays the increasing distance separating humans and the environment in late modernity. Seen through binoculars, mapped onto a piece of paper, or captured by the lens in the film, the mountains are now perceived through technology. Towards the end the film reflects once again upon the shift in our approach to the natural world. We see close-ups of trees common in that region of Portugal - an elm, an elder tree, an oak, and a chestnut tree-followed by 
signs indicating their scientific names. This suggests that most Portuguese would not be able to recognize the plants and indicates that a scientific approach to the landscape has replaced a more organic everyday connection to the world.

Perhaps the most apt illustration of this changing relationship to nature is the figure of the sound technician, Vasco Pimentel, one of the film crew members. Armed with his headphones and a large pole with a microphone at the tip, he records the sounds of the mountains and the forest. The environment and its sounds are only experienced with the aid of the microphone and are immediately recorded lest they vanish, as it happened to the forest after the fire. Mediated, digitally recorded sound becomes more real than environmental sound, in the same way as the image of the Beira mountains captured in the film is, for film viewers who have never been to the area, more concrete than the mountains themselves.

The last sequence of the movie is once again a meditation on modernity and the ways in which technology affects our connection to the environment. The film director Miguel complains to Vasco, the sound technician, about "sons fantasma" that plague natural shots in the movie they are making. In the middle of nature and without any loudspeakers in sight, one should hear no song, says Miguel. He wants to have "o som que existe" and points out that "não há canções na serra." To this, Vasco replies that he added nothing extraneous to the shots and that he faithfully reproduced the sounds he heard, which just happened not to be the same ones as those heard by other people. This staged dialogue humorously addresses the practice of inserting non-diegetic sounds such as music in the soundtrack of a film. In the case of Aquele querido mês de agosto, several shots of nature combine diegetic sounds such as the rustling of leaves with pop songs. In the dialogue, Miguel plays the role of the purist, striving for a strictly realistic effect and wanting only naturally existing sounds in the soundtrack. Vasco, however, dismantles the distinction between diegetic and non-diegetic sound and argues that the songs are there in nature. In other words, reality and artifice are empty categories in cinema. All sounds one hears in a film are fabricated in that they go through the process of being recorded and added to the shot as a soundtrack. Vasco goes even further, however, and makes the case for absolute relativism: people hear different things even if they share the same space; there is not one reality or one nature but reality and 
nature for each individual. In the film, nature is no longer a given landscape shared by an entire community but a precarious environment that one is free to experience in one's own idiosyncratic way.

The relation between Portuguese cinema and the natural world reflects the socio-economic and political changes the country has experienced over the past century. Some tropes have remained surprisingly stable from the silent period onwards: an exoticized image of the countryside, seen through the perspective of city dwellers; the interrelation between nature and rural activities and traditions; and the idea that the environment can be tamed, giving rise to a domesticated natural sublime. Still, the portrayal of the environment in film has also undergone profound transformations. In Estado Novo filmography nature was depicted as a powerful, sometimes wrathful god that humans needed to learn to work with in order to survive, authority figures being presented as avatars of this powerful force. Rural, communal existence, in tune with nature, was considered preferable to the more corrupt and decadent city life. Toward the end of Salazar's regime and during the first decades of democratic rule, the Novo Cinema movement problematized the growing urbanization of Portugal. It painted a picture of a society at odds with its surroundings, whose members felt at home neither in the impoverished rural areas, now largely abandoned, nor in the new, sprawling cities. More contemporary film productions have emphasized the divide separating humanity from the natural world, and underscored the fragility of the environment, threatened by human activities. Nature is now a vanishing signified, the signifier having replaced the real, whose very existence is put into question. What better medium than cinema, the realm of artifice, pretense and make-believe, to ponder the repercussions of this shift toward the virtual with respect to our relation to the world?

\section{Works Cited}

Baptista, Tiago. "Tipicamente Português. O Cinema Ficcional Mudo em Portugal no Início dos Anos Vinte.” MA Thesis, U Nova de Lisboa, 2003. Barros, Leitão de, director. Ala-Arriba! Tobis Portuguesa, 1942.

-. As Pupilas do Senhor Reitor. Tobis Portuguesa, 1935.

—. Maria do Mar. Sociedade Universal de Superfilmes, 1930.

—. Nazaré, Praia de Pescadores. Artur Costa de Macedo, 1929. 
Botelho, João, director. Um Adeus Português. Fundação Calouste Gulbenkian, 1986.

Campos, Henrique, director. Um Homem do Ribatejo. Filmes Albuquerque, 1946.

Canto, Jorge Brum do, director. A Canção da Terra. Produção de Jorge Brum do Canto e Aquilino Mendes, 1938.

-. A Cruz de Ferro. Tobis Portuguesa, 1967.

—. Lobos da Serra. Tobis Portuguesa, 1942.

Duncan, Pansy. "Shrubs and the City: Urban Nature in Rear Window." The Green Thread: Dialogues with the Vegetal World, edited by Patrícia Vieira, Monica Gagliano, and John Ryan, Lexington, 2016, pp. 219-32.

Fraga, Augusto, director. Sangue Toureiro. Produtores Associados, 1958.

Ferro, António. Teatro e Cinema (1936-1949). SNI, 1950.

Garcia, Chianca de, director. Aldeia da Roupa Branca. Tobis Portuguesa, 1939.

Gomes, Miguel, director. Aquele Querido Mês de Agosto. O Som e a Fúria, 2008.

Hitchcock, Alfred, director. Birds. Hitchcock Productions, 1963.

-. Rear Window. Paramount Pictures, 1954.

Lopes, Fernando, director. As Palavras e os Fios. Álvaro Belo Marques, 1962.

—. Uma Abelha na Chuva. Média Filmes, 1971.

Oliveira, Manoel de, director. Douro, Faina Fluvial. Manoel de Oliveira, 1931.

-. O Acto da Primavera. Lusomundo, 1962.

Pelicano, Jorge, director. Ainda há Pastores? Sociedade Independente de Comunicação, 2006.

Reis, António and Margarida Cordeiro, directors. Trás-os-Montes. Centro Português de Cinema, 1976.

Ribeiro, António Lopes, director. Gado Bravo. Bloco H. da Costa, 1934.

Ribeiro, M. Félix. Filmes, Figuras e Factos da História do Cinema Português 1896-1949. Cinemateca Portuguesa, 1983.

Rocha, Paulo, director. Os Verdes Anos. António da Cunha Teles, 1963.

Trier, Lars von, director. Dogville. Zentropa, 2003.

Vieira, Patrícia. Portuguese Film, 1930-1960: The Staging of the Estado Novo Regime. Bloomsbury, 2013. 